\title{
Counterproductive Work Behavior Among Government Employees: The Role of Basic Psychological Needs, Compensation, and Organizational Justice
}

\author{
Ahimsyah Wahyu Pratama ${ }^{a}$ and Endang Parahyanti ${ }^{b}$ \\ Indonesia \\ *Corresponding author: \\ Endang Parahyanti \\ Department of Industrial and Organizational Psychology \\ Faculty of Psychology, Universitas Indonesia \\ Jl. Lkr. Kampus Raya, \\ Depok, Jawa Barat Indonesia, 16424 \\ Tel.: +62 217270004 \\ Email address: parahyanti@gmail.com
}

${ }^{a}$ Faculty of Psychology, Universitas Indonesia, Depok, Indonesia $;{ }^{b}$ Department of Industrial and Organizational Psychology, Faculty of Psychology, Universitas Indonesia, Depok, 


\title{
Counterproductive Work Behavior Among Government Employees: The Role of Basic Psychological Needs, Compensation, and Organizational Justice
}

\begin{abstract}
This study examined the mediating role of perceived organizational justice (procedural, interpersonal, and distributive justice) dimensions in explaining the association between basic psychological needs (need for autonomy, competence, and relatedness), compensation, and counterproductive work behavior (CWB). The participants in this study were 277 employees from various government institutions (local government, ministries, and boards). Data were collected through convenience sampling and tested using Hayes's PROCESS Macro, from which support was found for the mediation model in which the association between basic psychological needs and CWB was mediated by the perceived organizational justice dimensions. Similar results were found for the association between compensation and CWB. The interesting finding from this study was that contrary to existing studies, compensation was found to have a positive direct effect with CWB-I, and if mediated by distributive justice, the coefficient was negative. These findings suggested several opportunities for organizational interventions aimed at minimizing the negative impact of CWB in government employees.
\end{abstract}

Keywords: basic psychological needs, compensation, counterproductive work behavior, organizational justice, self-determination theory.

\section{Introduction}

Counterproductive work behavior (CWB) has become a problem in many private and public organizations; however, the tendency has been observed to be higher in public sector organizations (Dick \& Rayner, 2012; Novrianti, 2014). CWB is defined as deviant employee behavior that harms or is intended to harm the organization or its members (Jacobs, Belschak \& Den Hartog, 2013; Penney \& Spector, 2005; Robinson \& Bennett, 1995), and specifically includes behaviors that interfere with the organization or members of the organization such as theft, sabotage, interpersonal aggression (both physical and verbal), deliberately working slowly, wasting time or supplies, and withdrawal such as absence or delays (Penney \& Spector, 2002; Spector, Fox, Penney, Bruursema, Goh, \& Kessler, 2006). Robinson and Bennet (1995) distinguished CWB directed at the organization (CWB-O) such as theft, fraud, sabotage, deliberately working slowly, and wasting resources, and CWB directed at individuals in the organization (CWB-I) such as verbal assault and aggression (Wu, Sun, Zhang, \& Wang, 2016)

Many Indonesian government employees have been found to engage in disciplinary violations, fraud, and poor job performance (Badjuri, 2011); for example, the Indonesian State Personnel Agency (Badan Kepegawaian Negara, BKN) reported that in 2017, 1,759 government employees were punished for $\mathrm{CWB}$, with the disciplinary punishment varying from severe to moderate to mild penalties. Punishment was mostly given for the 570 violations of the working hour provisions such as absenteeism or coming late to the office without permission 
(Humas BKN, 2018). Corruption by government employees has also become a problem, with 1,115 government employees being suspected of corruption between 2001 and 2015, which was $43.40 \%$ of all corruption cases in Indonesia (Pradiptyo, Partohap \& Pramashavira, 2016). Previous research has found that CWB can have a significantly negative impact on an organization (Aquino, Lewis, \& Bradfield, 2009) such as economic losses and sociopsychological impacts on the organization and other employees (Christian, \& Ellis, 2011; Coffin, 2013; Penney \& Spector, 2002). Therefore, this study seeks to extend current research and explore the variables that may minimize CWB in government employee settings that have attracted little research attention. Self-Determination Theory (SDT) and Social Exchange Theory (SET) are employed to explain the influence of basic psychological needs, compensation, and organizational justice in dealing with CWB.

SDT has been frequently used to explain organizational behavior. SDT theory is based on three basic psychological needs; the need for autonomy, the need for competence, and relatedness; with autonomy being defined as the individual need to determine one's own actions and behavior by feeling psychologically free, competence being the need to finish tasks effectively and master new knowledge and skills, and relatedness being feelings of connectedness and having sympathy for others (Deci \& Ryan, 2000; Sheldon, Turban, Brown, Barrick, \& Judge, 2016).

SDT states that as people have an innate tendency to be pro-social and engage in positive and productive behaviors, satisfaction with their basic psychological needs provides the necessary energy for the emergence of positive and productive behaviors. On the other hand, however, the lack of the satisfaction of these needs can lead to negative outcomes (Sheldon, Turban, Brown, Barrick, \& Judge, 2016). Satisfaction with basic psychological needs has also been found to be associated with increased psychological well-being and work performances (Deci \& Ryan, 2000; Deci, Ryan, Gagne, Leone, Usunov \& Kornazheva, 2001; Gagne, \& Deci, 2001). Kuvaas and Dysvik (2009) found that satisfying these three basic psychological needs led to a better quality of work, and Huang, et.al. (2017) found that satisfaction with the need for autonomy was positively related to the fulfillment of the need for competence and relatedness; therefore, satisfaction with the need for competence and relatedness was seen to be negatively related to CWB-O and CWB-I. However, feeling frustration with the lack of basic psychological needs can lead to negative organizational outcomes such as low welfare, commitment and performance (Van den Broeck, Vansteenkiste, De Witte, \& Lens, 2008), low self-control, and aggression (Vansteenkiste \& Ryan, 2013).

Another variable that has been observed to have some influence on CWB is compensation or the rewards employees receive for performing their job or task (Martocchio, 2001) such as basic salary, pay adjustments, other incentives, and all other forms of financial returns and tangible services and benefits that employees receive as part of the employment relationship (Milkovich, Newman, \& Gerhart, 2014). Compensation, therefore, is a very important component of human resources management and can significantly affect working behaviors. Economic agency theory states that as compensation promotes motivation and performance, if an organization provides employees with greater compensation to behave in a way to achieve 
the organization's goals, employees would be motivated to behave in those ways (Jensen \& Meckling, 1967).

\section{Mediation of Organizational Justice}

Although SDT argues that these three basic psychological needs are the most important and influential motivations for work behaviors, there are other organizational factors that have been seen as antecedents for both deviant and effective behaviors that are not specifically addressed in SDT, one of which is perceived organizational justice (Talaepashiri, 2016). Greenberg (1990) defined organizational justice as employee perceptions of the extent to which they think they are being treated fairly by the organization; that is, organizational justice reflects how fairly an individual feel that they are being treated in the workplace (Kreitner \& Kinicki, 2014). Colquitt (2001) divided organizational justice into three distinct dimensions: procedural justice (the perceived fairness of organizational decision-making processes), interactional justice (the perceived fairness of the interpersonal relationships within the organization), and distributive justice (the perceived fairness of the outcomes). In other words, procedural justice occurs when there is fairness in the processes used to determine outcomes (Thibaut \& Walker, 1975), distributive justice occurs when there is an equal distribution of outcomes and resources (Adams, 1965), and interactional justice is the perceived compatibility between the employee and another organizational members (Boulding, 1963)

The association between CWB and the three basic SDT psychological needs variables (need for autonomy, competence, and relatedness), compensation, and the mediating role of the perceived organizational justice dimensions can be explained by social exchange theory (SET). SET, which has been used for many years to understand workplace behavior, posits that employees reciprocate unfair and unjust treatment by an organization through CWB (Andrews \& Kacmar, 2001). When employees perceive that organizational procedures are unfair, they punish those responsible for the inequity to restore justice (Aquino, Tripp \& Bies, 2006). Conversely, a social exchange takes place if an organization is willing to take actions that are of value to the employees, ensuring that there is justice at work (Cropanzano \& Rupp, 2003). In the context of SDT, social exchange occurs when an organization is able to satisfy the three basic needs. The link between the satisfaction of these three basic needs and the level of organizational justice will direct employees to increase their work performance (Mayer, Bardes, \& Piccolo, 2008).

Cohen-Charsh and Spector (2001) suggested that CWB was a reaction to a perception of organizational injustice. From a procedural justice perspective, these perceptions of injustice give rise to negative perceptions of the organization and lead to CWB that can be detrimental to the organization (Hershcovis, Turner, Barling, Arnold, Dupre, Innes, LeBlanc \& Sivanathan, 2007; Liu, Bowling, Huang \& Kent, 2013). Fox, Spector, and Miles (2001) found that procedural injustice was related to organizational CWB (CWB-O), while interpersonal conflict or interactional justice was related to individual CWB (CWB-I). However, when there is percieved distributive injustice, people may react by counterproductively reducing inputs, or by acting aggressively toward the person who appears to be the cause of the injustice (CohenCharsh \& Spector, 2001). As procedural justice is related to the organizational level (Aquino, 
Lewis \& Bradfield, 2009), it is more likely to be related to CWB directed toward the organization (Skarlicki \& Folger, 1997).

Based on the above theories and research, this study first developed a framework representing the association between the basic psychological needs (need for autonomy, competence, and relatedness), compensation, and CWB that includes the mediating role of the perceived organizational justice dimensions, and then developed four research hypotheses, as follows:

H1: The association between satisfaction with the need for autonomy and CWB-O is mediated by procedural justice.

$\mathrm{H} 2$ : The association between satisfaction with the need for competence and CWB-O is mediated by procedural justice.

H3: The association between satisfaction with the need for relatedness and CWB-I is mediated by interactional justice.

H4: The association between compensation and CWB-I is mediated by distributive justice.

\section{Method}

\section{Participants}

The study participants were 277 employees from various Indonesian government institutions (local government, ministries, and boards), who were selected using convenience sampling. These employees participated voluntarily and anonymously. Most participants were male $(56.3 \%)$ and aged $18-37$ years from the millennial generation $(74.4 \%)$, had 5-10 years tenure $(56 \%)$ and received a salary of between $7-10$ million rupiah a month $(42 \%)$.

\section{Measures}

CWB

CWB was measured using a short version of the Counterproductive Work Behavior Checklist (CWB-C) (Spector, Bauer \& Fox, 2010). The CWB-C categorizes CWB into CWB directed toward the organization (CWB-O) and CWB directed toward individuals (CWB-I), with the responses being given on six-point Likert scale ranging from 1 (never) to 6 (always). Reliability tests found the CWB-C questionnaire to be reliable, with the CWB-O dimension having an alpha coefficient of $(\alpha)=.75$ and the CWB-I dimension having an alpha coefficient of $(\alpha)=.80$, and the overall CWB-C having an alpha coefficient of $(\alpha)=.80$.

\section{Basic Psychological Needs}

Basic psychological needs were measured using the Work Related-Basic Need Satisfaction (W-BNS) (Van den Broeck, Vansteenkiste, De Witte, Soenens, \& Lens, 2010), which had 18 items to measure satisfaction, dissatisfaction, or frustration with the three basic psychological needs dimensions; autonomy, competence, and relatedness; with responses given on six-point Likert scale ranging from 1 (strongly disagree) to 6 (strongly agree). Reliability tests found that the W-BNS questionnaire was reliable, with the autonomy dimension having an alpha coefficient of $(\alpha)=.80$, the competence dimension having an alpha coefficient of $(\alpha)=.86$, the relatedness dimension having an alpha coefficient of $(\alpha)=.77$, and the overall W-BNS measurement having an alpha coefficient of $(\alpha)=.85$. 


\section{Organizational Justice}

Organizational Justice was measured using a short version of Colquitt's Organizational Justice Scale (Elovainio, Heponiemi, Hannamaria, Sinervo, Hintsa, \& Aalto, 2010), which has eight items that measure the perception of organizational justice or fairness across the three procedural, distributive, and interactional justice dimensions, with the responses being indicated on a six-point Likert scale ranging from 1 (strongly disagree) to 6 (strongly agree). Reliability tests found the OJS questionnaire to be reliable, with the procedural justice dimensions having an alpha coefficient of $(\alpha)=.83$, interactional justice having an alpha coefficient of $(\alpha)=.90$, distributive justice having an alpha coefficient of $(\alpha)=.92$, and the overall OJS having an alpha coefficient of $(\alpha)=.80$.

\section{Compensation.}

The compensation variable was determined from the salary and incentives received by the employees in the month the study was conducted. The compensation data were collected from the demographic participant data on the questionnaire and grouped into five categories; 3 to 5 million rupiah, 5 to 7 million rupiah, 7 to 10 million rupiah, 10 to 15 million rupiah, and over 15 million rupiah a month.

\section{Analysis}

The mediation model used in this study was tested using model 4 of Hayes's PROCESS Macro version 2.16.3 in SPSS 24. This study used a 95\% confidence interval and 10,000 bootstraps.

\section{Results}

\section{Descriptive Statistics}

The mean and standard deviations for all variables for all compensation categories are shown in Table 1, from which the following compensation overview was determined: (1) the mean CWB-O was low in all compensation categories, with the highest mean being for employees paid 7-10 million ( $\mathrm{M}=2.08, \mathrm{SD}=.52)$ rupiah a month; (2) the mean CWB-I was also low in all compensation categories, with the highest mean being for employees paid 7-10 million $(\mathrm{M}=1.64, \mathrm{SD}=.56)$; (3) employees paid $>15$ million had the highest satisfaction with the need for autonomy compared to the other compensation categories $(\mathrm{M}=5.08, \mathrm{SD}=1.00)$; (4) employees paid 3-5 million had the highest satisfaction with the need for competence $(\mathrm{M}=4.90, \mathrm{SD}=.84)$ and relatedness $(\mathrm{M}=4.77, \mathrm{SD}=.85)$; (5) the highest perception of procedural justice was felt by employees paid >5-7 million $(\mathrm{M}=3.57, \mathrm{SD}=1.10)$; and (6) employees paid $>15$ million a month felt the highest perception of interactional $(\mathrm{M}=4.54, \mathrm{SD}=1.07)$ and distributive justice $(\mathrm{M}=4.71, \mathrm{SD}=1.13)$.

Table I. Mean and Standard Deviation

\begin{tabular}{|l|l|l|l|l|l|l|l|l|}
\hline \multirow{3}{*}{ Variables } & \multicolumn{9}{l}{ Compensation } \\
\cline { 2 - 9 } & $3-5$ & \multicolumn{1}{l|}{$>5-7$} & \multicolumn{2}{l|}{$>-10$} & \multicolumn{1}{l|}{$>$} \\
\cline { 2 - 9 } & $M$ & SD & $M$ & SD & $M$ & SD & $M$ & SD \\
\hline AUTO & 4.81 & 1.03 & 4.92 & .98 & 4.80 & 1.03 & 5.08 & 1.00 \\
\hline COMP & 4.90 & .84 & 4.79 & .72 & 4.53 & .73 & 4.82 & .75 \\
\hline
\end{tabular}




\begin{tabular}{|l|l|l|l|l|l|l|l|l|}
\hline RELA & 4.77 & .85 & 4.62 & .81 & 4.50 & .87 & 4.75 & .91 \\
\hline PROJ & 3.25 & 1.07 & 3.57 & 1.10 & 3.51 & 1.04 & 3.42 & 1.12 \\
\hline INTJ & 4.27 & 1.24 & 4.48 & .86 & 4.25 & 1.00 & 4.54 & 1.07 \\
\hline DISJ & 3.62 & 1.44 & 4.26 & 1.15 & 4.02 & 1.09 & 4.71 & 1.13 \\
\hline CWB-O & 2.03 & .63 & 1.99 & .54 & 2.08 & .52 & 1.70 & .47 \\
\hline CWB-I & 1.43 & .49 & 1.53 & .50 & 1.64 & .56 & 1.62 & .86 \\
\hline
\end{tabular}

Note, $\mathrm{AUTO}=$ need for autonomy, $\mathrm{COMP}=$ need for competence, RELA=need for relatedness,

PROJ=procedural justice, INTJ=interactional justice, DISJ=distributive justice, CWB-O= organizational counterproductive work behavior, CWB-I= individual counterproductive work behavior.

\section{Bivariate Correlations}

Based on the correlations, it was observed that CWB-O had significant correlations with the three basic psychological need dimensions and the three organizational justice dimensions. Similarly, CWB-I was found in have significant correlations with the basic psychological need dimensions with the exception of the need for competence as well as the the perceived organizational justice dimensions.

An interesting finding was that compensation had no significant correlation to either CWB-O or CWB-I. However, the data indicated that compensation was positively correlated with CWB-I, which means that as the compensation increased, the tendency to be involved in CWB-I also increased. The means, standard deviations, and correlations for all variables are shown in Table 3.

\section{Hypothesis Testing}

It was found that satisfaction with the need for autonomy was associated with CWB-O indirectly through procedural justice (Effect $=-.0610, \mathrm{SE}=.0201, \mathrm{LLCI}=-.1054$, ULCI $=$ $-.0253)$, which supported hypothesis 1.

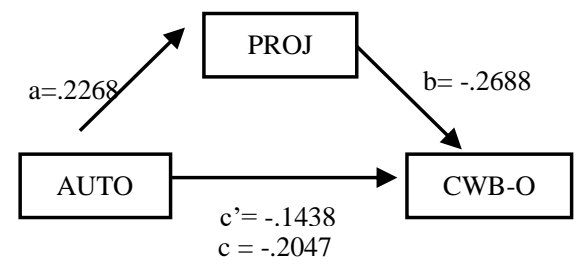

Satisfaction with the need for competence was found to be associated with CWB-O indirectly through procedural justice (Effect $=-.0435, \mathrm{SE}=.0181$, LLCI $=-.0863$, ULCI $=-.0140$ ), which supported hypothesis 2 .

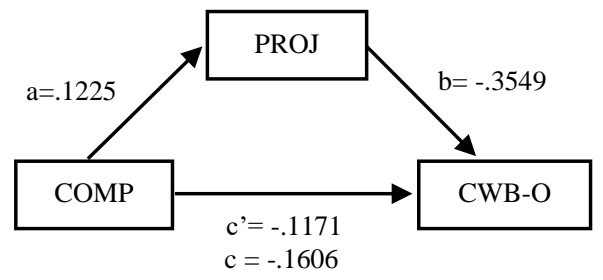


Satisfaction with the need for relatedness was found to be associated CWB-I indirectly through interactional justice (Effect $=-.0468, \mathrm{SE}=.0164, \mathrm{LLCI}=-.0893$, ULCI $=-.0228$ ), which supported hypothesis 3 .

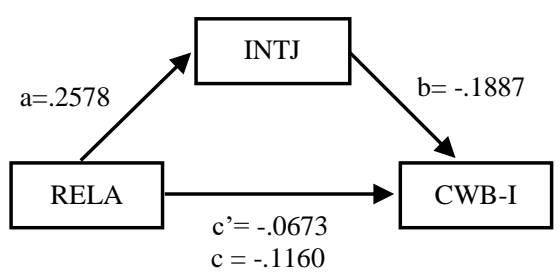

Compensation was associated with CWB-I indirectly through distributive justice (Effect = $-.0650, \mathrm{SE}=.0420, \mathrm{LLCI}=-.1760, \mathrm{ULCI}=-.0030$ ), which supported hypothesis 4 .

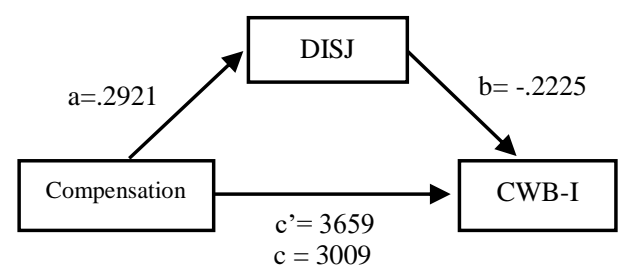

\section{Discussion}

This research sought to determine the relationships with CWB as one type of deviant behavior. Specifically, this study analyzed the mediating roles of perceived procedural, interactional, and distributive justice in explaining the associations between basic psychological needs, compensation, and CWB, from which there were the following findings.

First, hypotheses 1, 2, and 3 were supported. The association between the three basic psychological needs and a decreased CWB was mediated by increased organizational justice, which was consistent with previous research that found that when basic psychological needs are satisfied, people have positive outcomes such as better performances, more positive emotions, and more fulfilling relationships (Chirkov, Ryan, \& Sheldon, 2011; Deci \& Ryan, 2002)

The experience of being satisfied with the need for autonomy, competence, and relatedness gives employees some certainty regarding the organization's commitment to employee fairness. In contrast, the experience of being frustrated with the need for autonomy, competence, and relatedness increases the possibility for employees to perceive injustice. As found in previous research, organizational justice is related to need satisfaction (Cohen-Charsh $\&$ Spector, 2001) and unfair treatment at work such as abusive supervision has been found to negatively relate to need satisfaction (Lian, Ferris, \& Brown, 2012).

Based on SET, it was proposed that perceived organizational justice could serve as a mediating mechanism in the association between basic psychological needs and CWB. Low organizational justice can lead to hostile work environments and reduce the perceived capacity 
to work. If employees work in this type of environment for a long time, they tend to engage in CWB to make up for the unfairness in the organization (Lian, Ferris, \& Brown, 2012). Employees that perceive injustice are more likely to engage in CWB. Flaherty and Moss (2007) claimed that "Organizational justice is a mediator of CWB, as it suggests that individuals who perceived their own workgroup to receive more justice than other units, engaged in less counterproductive work behavior" (Flaherty \& Moss, 2007).

Needs satisfaction provides the nutrients that enable employees to perceive organizational justice, which in turn makes them internalize the self-regulatory processes that engender goaldirected behavior (Bolton, Harvey, Grawitch, \& Barber, 2012) and reduce the tendency to engage in CWB. Following the needs model of justice (Aryee, Budhwar, \& Chen, 2002; Colquitt, Greenberg \& Scott, 2005), it was argued that satisfaction with the need for autonomy, competence, and relatedness provides the nutrients that foster organizational justice, which is negatively related to CWB through increased motivation, which is an antecedent to CWB, and provides a further extension of SDT into organizational settings.

Second, even though hypothesis 4 was supported; that is, the mean compensation was found to be associated with CWB-I through the mediating role of distributive justice; it was also found that compensation was positively correlated to CWB-I, indicating that the higher the compensation, the greater the tendency to be engaged in CWB-I. This finding differed from previous studies that have generally reported a positive compensation effect on employee performance, and was also different from traditional economic agency theory (Gerhart \& Rynes, 2003) that claims that if an organization provides employees with increased compensation when their behaviors help the organization meet its goals, the employees are motivated to behave in "productive" ways.

However, if distributive justice is employed as a mediator in the relationship between compensation and CWB-I, the coefficient becomes negative, which indicates that to reduce CWB-I, compensation distribution is more important for the employees need to feel justice rather than the compensation alone. This finding was supported by previous studies in which it was found that compensation was a predictor of distributive justice, and that distributive justice decreases CWB tendencies. Gagne and Forest (2008) concluded that as distributive justice is related to how people feel about the compensation they are receiving, it is logical to surmise that when employees receive increased compensation, they experience greater distributive justice and are more likely to demonstrate the behaviors expected by the organization. 
TABLE 2. MEANS, STANDARD DEVIATION, BIVARIATE CORELLATIONS

\begin{tabular}{|c|c|c|c|c|c|c|c|c|c|c|c|}
\hline Variables & $M$ & SD & 1 & 2 & 3 & 4 & 5 & 6 & 7 & 8 & 9 \\
\hline 1. AUTO & 19.48 & 4.03 & - & & & & & & & & \\
\hline 2. COMP & 18.78 & 3.01 & $.314^{* *}$ & - & & & & & & & \\
\hline 3. RELA & 18.39 & 3.39 & $.418^{* *}$ & $.351^{* *}$ & - & & & & & & \\
\hline 4. Compensation & 2.52 & 0.93 & .021 & -.087 & -.032 & - & & & & & \\
\hline 5. PROJ & 7.01 & 2.15 & $.425^{* *}$ & $.172^{* *}$ & $.215^{* *}$ & .012 & - & & & & \\
\hline 6. INTJ & 13.10 & 2.94 & $.386^{88}$ & $.146^{*}$ & $.298^{* 8}$ & -.003 & $.205^{* *}$ & - & & & \\
\hline 7. DISJ & 8.25 & 2.36 & $.267^{* 8}$ & .055 & $.245^{* *}$ & .115 & $.258^{* 8}$ & $.379^{* *}$ & - & & \\
\hline 8. CWB-O & 10.07 & 2.71 & $-.304^{* 8}$ & $-.179^{* *}$ & $-.198^{* 8}$ & -.071 & $-.304^{* 8}$ & $-.229^{* *}$ & $-.222^{* 8}$ & - & \\
\hline 9. CWB-I & 7.85 & 2.81 & $-.275^{* 8}$ & -.099 & $-.141^{*}$ & .100 & $-.221^{* 8}$ & $-.222^{* *}$ & $-.174^{* 8}$ & $.496^{* *}$ & - \\
\hline
\end{tabular}

Nonetheless, the common belief that reasonable compensation promotes motivation and performance and reduced the tendency for CWB was not confirmed in the present research, as compensation was not found to have any significant correlation to either CWB-O or CWB-I, which seems to indicate that compensation is not a factor when employees decide to engage in CWB. This finding may have been because the Indonesian government compensation management is generally not based on contribution or performance as all employees receive the same periodic pay adjustments and incentives are associated with specific job levels, which means that employees that feel they give maximum contribution and performance could feel a sense of injustice. Equity Theory states that employees perceive fairness when they think that their work and output is similar to others, which then increases their motivation and performance. On the other hand, if the compensation is perceived to be inequitable, employees may be demotivated (Adams, 1965), which could lead to CWB-I toward other individuals in the organization such as coworkers and supervisors (Penney \& Spector, 2006).

\section{Practical Implications}

This study found that basic psychological needs and organizational justice need to be considered when seeking to minimize CWB in Indonesian government employees. These findings could assist government institutions create workplace environments that support the employees' basic psychological needs and formulate adequate and fair compensation so that all employees perceive fairness, which would minimize the possibility of CWB.

Based on the results of this study, the following organizational interventions are suggested to minimize CWB in government employees.

First, organizations need to promote basic psychological needs satisfaction. To enhance satisfaction with the need for autonomy, organizations could develop job designs that allow employees to determine their own actions and behavior. Organizations also have to encourage managers to practice transformational leadership (managers who are charismatic, inspirational, and considerate toward subordinates) (Bono \& Judge, 2003). To deal with the need for competence, organizations should attract and retain employees and provide periodic training to 
improve employee competencies. The need for relatedness can be satisfied by fostering social support and trust among employees.

Second, organizations need to focus on a ensuring a sound organizational justice climate in the workplace as the employees' perceived organizational justice influences whether they react constructively or destructively to an apparent unfair event (Bobocel, 2013). Further, when employees are treated unfairly, the organization must have organizational policies that can restore their employees' perceptions of organizational justice (Reb, Goldman, Kray, \& Cropanzano, 2006). One suggestion would be to implement succession planning based on merit or applying a job bidding mechanism to increase career management transparency. Allowing employees to participate in decision making and providing meaningful information to make decisions could also assist employees to better understand the organizational process and would increase employee perceptions of procedural and interactional justice (Nazrudin, Ahmad, \& Razalli, 2014).

Third, annual organizational surveys could be conducted to monitor employee satisfaction with their needs for autonomy, competence, and relatedness, and perceptions of procedural, interactional, and distributive justice to assess employee CWB tendencies. The survey results could then be used to determine the interventions and policies required to reduce CWB. Employees also need to be made aware of their CWB offenses such as leaving early, coming late to work without permission or making fun of someone at work, as they may not be aware that these are CWB. When employees are made aware of their CWB and informed that it is undesirable, their guilty feelings could motivate them to display more positive and productive organizational citizenship behavior (Ilies, Scott, \& Judge, 2006).

Finally, government compensation policies need to be related to employee performance appraisals so that employee compensation is based on productivity and performance. However, the performance appraisals must be fair and equally applied to all if they are to be used as the basis for determining compensation (Gagne, M, and Forest, 2008).

\section{Limitations and Directions for Future Research}

There were some limitations in this study. First, because the participants were selected using convenience sampling, the participant's characteristics were less diverse. The sample was dominated by millennials (74.4\%) who worked in staff level positions (97\%). To enhance the generalizability of study findings, future studies should consider stratified random sampling to obtain more diverse participants.

Second, even though the sample was moderately large, most participants worked for central government agencies or ministries $(86.3 \%)$ and only a few worked for local government $(13.7 \%)$; therefore, future research should seek data from a balance of central and local government employees.

A third limitation was that the present study used a cross-sectional and self-report design. Although the study was (1) anonymous, (2) stressed that there were no wrong or right 
answers, and (3) used a Likert scale that measured the frequency of being involved in certain behaviors rather than using a CWB measurement, there was still a possibility that a variance common method was present. Therefore, future studies need to consider the use of experimental and longitudinal studies to reveal the relative roles of between-individual and within-individual variations in the variable associations. It also suggested that co-worker or supervisor report questionnaires be employed to measure CWB to provide a possible theoretical framework for analyzing the delayed effect of the level of perceived organizational justice on CWB and shed light on the processes through which employee justice perceptions are linked to CWB and other work-related outcomes.

\section{Conclusions}

This study found support for a mediation model in which the association between three basic psychological needs; the need for autonomy, competence, and relatedness; and CWB was mediated through the organizational justice dimensions. Similar results were found for the associations between compensation and CWB. In addition, our study provided new insights into the role of perceived distributive justice in the associations between compensation and CWB. These findings also suggested several opportunities for organizational interventions aimed at minimizing the negative impact of CWB in government employees by promoting basic psychological needs satisfaction, compensation management, and organizational justice.

\section{References}

Adams, J. S. (1965). Inequity in social exchange. In L. Berkowitz (Ed.), Advances in experimental social psychology. New York: Academic Press.

Andrews, M. C, \& Kacmar, K. M. (2001). Discriminating among organizational politics, justice, and support. Journal of Organizational Behavior, 22, 347-366.

Aquino, K., Lewis, M. U., \& Bradfield, M. (2009). Justice constructs, negative affectivity, and employee deviance: A proposed model and empirical test. Journal of Organizational Behavior, 20, 1073-1091.

Aquino, K., Tripp, T. M, \& Bies, R. J. (2006). Getting even or moving on? Power, procedural justice, and types of offense as predictors of revenge, forgiveness, reconciliation, and avoidance in organizations. Journal of Applied Psychology, 91, 653-668.

Aryee, S., Budhwar, P. S. \& Chen, Z. X. (2002), Trust as a mediator of the relationship between organizational justice and work outcomes: Test of a social exchange model. Journal of Organizational Behavior, 23, 267-285.

Badjuri, A. (2011). Faktor-faktor yang berpengaruh terhadap kualitas audit auditor independen pada kantor akuntan publik (KAP) di Jawa Tengah, Dinamika Keuangan dan Perbankan, 3, Nomor 2.

Bobocel, D. R. (2013). Coping with unfair events constructively or destructively: The effects of overall justice and self-other orientation. Journal of Applied Psychology, 98, 720-731.

Bolton, L. R., Harvey, R. D., Grawitch, M. J. \& Barber, L. K. (2012). Counterproductive work behaviours in response to emotional exhaustion: A moderated mediational approach. Stress and Health, 28, 222-233.

Bono, J. E, \& Judge, T. A, (2003). Self-concordance at work: Understanding the motivational effects of transformational leaders. Academy of Management Journal, 46, 554-571

Boulding, K. E. (1963). The University, Society, and Arms Control. Journal of Conflict Resolution, 7, 458-463.

Chirkov, V. I., Ryan, R. M., \& Sheldon, K. M. (2011). Human autonomy in cross- cultural context: Perspectives on the psychology of agency, freedom, and well-being. Dordrecht: Springer. 
Christian, M. S., \& Ellis, A. P. (2011). Examining the effects of sleep deprivation on workplace deviance: A self-regulatory perspective. Academy of Management Journal, 54, 913-934.

Coffin, B. (2003). Breaking the silence on white collar crime. Risk Management, 50, 8-10.

Cohen-Charash, Y, \& Spector, P. E, (2001). The role of justice in organizations: A meta-analysis. Organizational Behavior and Human Decision Processes, 86, 278-321.

Colquitt, J. A, Greenberg, J, \& Scott, B. A. (2005). Organizational justice: where do we stand? In J. A. Colquitt \& J. Greenberg (Eds.), The Handbook of Organizational Justice (pp. 589-619). Mahwah, NJ: Erlbaum.

Colquitt, J. A. (2001). On the dimensionality of organizational justice: A construct validation of a measure. Journal of Applied Psychology, 86, 386-400.

Cropanzano. R. \& Rupp, D. (2003). An overview of organizational justice: implications for work motivation, Motivation and Work Behavior. Boston, MA: McGraw-Hill.

Deci, E. \& Ryan, R. (2002). Handbook of Self-Determination Research. Rochester, NY: The University of Rochester Press.

Deci, E. L, \& Ryan, R. M. (2000). The what and why of goal pursuit: Human need and the self-determination of behavior. Psychology Inquiry, 11, 227-268.

Deci, E. L., Ryan, R. M., Gagne, M., Leone, D. R., Usunov, J., \& Kornazheva, B. P. (2001). Need satisfaction, motivation, and well-being in the work organization of a former Eastern block country: Across-cultural study of self-determination. Personality and Social Psychology Bulletin, 27, 930-942.

Dick, G. P. M., \& Rayner, C. (2012). Negative interpersonal behavior at work: An evidence based classification of workplace bullying. International Journal of Psychology and Behavioral Sciences, 3, 95-108.

Elovainio, M, Heponiemi, T, Hannamaria, K, Sinervo, T, Hintsa, T, \& Aalto, A. (2010). Developing a short measure of organizational justice: A multisample health professionals study. Journal of Occupational and Enviromental Medicine, 52, 1068-1074

Flaherty, S., \& Moss, S. A. (2007). The impact of personality and team context on the relationship between workplace injustice and counterproductive work behavior. Journal of Applied Social Psychology, 37, 2549-2575.

Fox, S., Spector, P. E., \& Miles, D. (2001). Counterproductive work behavior (CWB) in response to job stressors and organizational justice: Some mediator and moderator tests for autonomy and emotions. Journal of Vocational Behavior, 59, 291-309.

Gagne, M. \& Deci, E. L. (2005). Self determinationtheory and work motivation. Journal of Organizational Behavior, 26, 331-62.

Gagne, M. \& Forest, J. (2008). The study of compensation systems through the lens of self determination theory: Reconciling 35 years of debate. Canadian Psychology, 49, 225-232.

Gerhart, B, \& Rynes, S. L. (2003). Compensation: Theory, Evidence, and Strategic Implications. Thousand Oaks, CA: Sage.

Greenberg, J. (1987). A taxonomy of organizational justice theories. Academy of Management Review, 12, 9-22.

Hershcovis, M. S., Turner, N., Barling, J., Arnold, K. A., Dupre, K. E., Innes, M., LeBlanc, M. M., \& Sivanathan, N. (2007). Predicting workplace aggression: A meta-analysis. Journal of Applied Psychology, 92, $228-238$.

Huang, R. T., Sun, H., Hsiao, C., \& Wang, C., (2017). Minimizing counterproductive work behavior: The role of self-determined motivation and perceived job insecurity in organizational change. Journal of Organizational Change Management, 30,15-26.

Humas B. K. N. (2018). Press release: Sebanyak 1.759 PNS Dijatuhi Hukuman Disiplin Pada Tahun 2017. Retrieved from http://www.bkn.go.id/wp-content/uploads/2018/02/7-Februari-2017-SIARAN-PERSHD-PNS-2017-1.pdf.

Ilies, R., Scott, B. A., and Judge, T. A. (2006). The interactive effects of personal traits and experienced states on intra-individual patterns of citizenship behavior. Academy of Management Journal, 49, 561-575.

Jacobs, G., Belschak, F. D., \& Den Hartog, D. N. (2013). (Un)ethical behavior and performance appraisal: the role of affect, support, and organizational justice. Journal of Business Ethics, 121, 1-14

Jensen, M. C. \& Meckling, W. H. (1976). Theory of the firm: Managerial behavior, agency costs, and ownership structure. Journal of Financial Economics, 3, 305-360

Kreitner, R. and Kinicki, A. (2014). Organizational Behavior, 9th ed. Jakarta: Salemba Empat. 
Kuvaas, B., \& Dysvik, A., (2009). Perceived invesment in employee development, intrinsic motivation and work performance. Human Resource Management Journal, 19, 217-236.

Lian, H., Ferris, D. L. \& Brown, D. J. (2012). Does taking the good with the bad make things worse? How abusive supervision and leader-member exchange interact to impact need satisfaction and organizational deviance. Organizational Behavior and Human Decision Processes, 117, 41-52.

Liu, M., Bowling, N. A., Huang, J. L., \& Kent, T.A. (2013). Insufficient effort responding to surveys as a threat to validity: The perceptions and practices of siop members. The Industrial-Organizational Psychologist, 51, 32-38.

Martocchio, J. J. (2001). Strategic Compenstion: A Human Resource Management Approach, 3rd ed. Upper Saddle River, NJ: Pearson.

Mayer, D. M, Bardes, M, \& Piccolo, R. F, (2008). Do servant-leaders satisfy follower need? an organizational justice perspective. European Journal of Work and Organizational Psychology, 17, 180-197.

Milkovich, G. T, Newman, J. M, \& Gerhart, B. A. (2014). Compensation, 11th Ed. New York, NY: McGraw Hill/Irwin.

Mingzheng, W., Xiaoling, S., Delin, Z., \& Ci, W. (2016). Moderated mediation model of relationship between perceived organizational justice and counterproductive work behavior. Journal of Chinese Human Resource Management, 7, 64-81.

Nazrudin, A. M, Ahmad, N. H, \& Razalli, A. A, (2014). Politics, justice, stress, and deviant behavior in organizations: An empirical analysis. International Journal of Business and Society, 15, 235-254.

Novrianti, D. P. (2014). Pengaruh Keadilan Organisasional pada Perilaku Kerja Kontraproduktif dengan Kepemimpinan Transformasional sebagai Variabel Pemoderasi (Master Thesis). Universitas Gajah Mada, Yogyakarta, Indonesia.

Penney, L. M., \& Spector, P. E. (2005). Job stress, incivility, and counterproductive work behavior (CWB): The moderating role of negative affectivity. Journal of Organizational Behavior, 26, 777-796.

Penney, L. M., \& Spector, P. E. (2002). Narcicism and counterproductive work behavior: Do bigger egos meas bigger problems?. International Journal of Selection and Assessment, 10, 126-134.

Pradiptyo, R., Partohap, H., Pramashavira. (2016). Korupsi Struktural: Analisis Database Korupsi Versi 4 tahun 2001-2015. Yogyakarta: Laboratorium Ilmu Ekonomi UGM.

Reb, J., Goldman, B. M., Kray, L. J., \& Cropanzano, R. (2006), Different wrongs, different remedies? Reactions to organizational remedies after procedural and interactional injustice. Personnel Psychology, 59, 31-64.

Robinson, S. L., \& Bennett, R. J. (1995). A typology of deviant workplace behaviors: A multidimensional scaling study. Academy of Management Journal, 38, 555-572.

Sheldon, K. M., Turban, D. B., Brown, G., Barrick, M. R., \& Judge, T. A. (2003). Applying self-determination theory to organizational research. In J. J. Martocchio \& G. R. (Eds.), Research in Personnel and Human Resource Management (pp. 357-393. Oxford: Elsevier Press.

Skarlicki, D. P. \& Folger, R. (1997). Retaliation in the workplace: The roles of distributive, procedural, and interactional justice. Journal of Applied Psychology, 82, 434-443.

Spector, P. E, Fox, S, Penney, Lisa, M, Bruursema, K, Goh, A, \& Kessler, S. (2006). The dimensionality of counterproductivity: are all counterproductive behavior created equal? Journal of Vocational Behavior, 68, 446-460.

Spector, P. E., Bauer, J. A. \& Fox, S. (2010). Measurement artifacts in the assessment of counterproductive work behavior and organizational citizenship behavior: do we know what we think we know? Journal of Applied Psychology, 95, 781-790.

Talaepashiri, A. R. (2016). Testing a need satisfaction approach to organizational citizenship behaviors and counterproductive work behaviors (Doctoral dissertation). University of Windsor, Ontario, Canada.

Thibaut, J., \& Walker, L. (1975). Procedural justice: A psychological analysis. Hillsdale, NJ: Erlbaum.

Van den Broeck, A., Vansteenkiste, M., De Witte, H. \& Lens, W. (2008). Explaining the relationships between job characteristics, burnout and engagement: the role of basic psychological needs satisfaction. Work and Stress, 22, 277-294.

Van den Broeck, A., Vansteenkiste, M., De Witte, H., Soenens, B., \& Lens, W. (2010). Capturing autonomy, competence, and relatedness at work: Construction and initial validation of the Work-Related Basic Need Satisfaction scale. Journal of Occupational and Organizational Psychology, 83, 981-1002. 
Vansteenkiste, M, \& Ryan, R. M. (2013). On psychological growth and vulnerability: Basic psychological needs satisfaction and need frustration as a unifying principle. Journal of Psychotherapy Integration, 23, 263280. 